\title{
THE FIGURE IN THE LANDSCAPE: A COMPARATIVE SKETCH OF DIRECTORS' SELF-INTERESTED TRANSACTIONS
}

\author{
Deborah A. DEMotT*
}

\section{INTRODUCTION}

A central question that underlies many analyses of corporate governance is whether the law and legal institutions have a constituent role in shaping governance practices, or whether the law, as well as governance practices, are best viewed as the inevitable results of market forces, centered upon capital markets. A separate, but related question is the degree to which mechanisms of governance-such as shareholder voting, take-over bids, independent directors, mandatory disclosure, and shareholder litigation-can function adequately as substitutes for one another. The perspective I offer on these questions is based on a comparison between the United States and the United Kingdom, which are sufficiently similar in relevant respects that their divergences are illuminating.

The Law Commissions of England and Scotland recently released a Consultation Paper surveying U.K. law on directors' duties with a particular focus on Part X of the Companies Act 1985, which addresses specific types of selfdealing by directors. ${ }^{1}$ Reading the Consultation Paper is an instructive experience for one familiar with corporate law in the United States because it confounds conventional wisdom about the degree of similarity between corporate law in the two countries. The descriptive as well as the evaluative portions of the Paper suggest that underlying principles diverge more between the United States and the United Kingdom than often is assumed. In particular, each country's body of law reflects different assumptions about the appropriate role of specific institutions in shaping the conduct of corporate directors and man-

Copyright $@ 2000$ by Deborah A. DeMott

This article is also available at http://www.law.duke.edu/journals/62LCPDeMott.

* Professor of Law, Duke University.

An earlier version of this paper was presented at the conference, "Defining Directors' Duties," organized by the Centre for Corporate and Commercial Law at the University of Cambridge, on December 5,1998. For helpful comments on the paper, I am grateful to Michael Bradley, Brian Cheffins, James D. Cox, Ernst G. Maug, Geoffrey P. Miller, Justice G.H.W. Santow, and Struan Scott.

This article was first published, in slightly different form, in 2 COMPANY, FIN. \& INSOLVENCY L. REV. 190 (1999), and is reprinted with the permission of the editor and Mansfield Press.

1. THE LAW COMMISSION \& THE SCOTTISH LAW COMMISSION, COMPANY DiRECTORS: REgulating CONFLicts of INTERESTS AND Formulating A STATEMENT OF DUTIES: A JoINT COnSultation PAPer (Law Commission Consultation Paper No. 153; Scottish Law Commission Discussion Paper No. 105) (1998) [hereinafter CONSUlTATION PAPER]. 
agers.

The degree of some of the substantive contrasts is striking. For example, the U.K. statute criminalizes particular transactions that, in the United States, would be well within the discretion of financially disinterested directors. As legislation, moreover, Part X of the Companies Act 1985 has a style and feel that is distinctly different from counterpart provisions in U.S. corporation statutes. Finally, the Consultation Paper illustrates the difficulty of rethinking settled doctrines and statutory structures within the law, so pervasive and inescapable is the force of underlying assumptions. Even analyses grounded in economics may reflect starting assumptions drawn not from economic principles of general applicability, but from a specific legal context.

In this article, I focus on the subject of Part X-transactions involving selfinterested directors-drawing contrasts with corporate law in the United States. I focus primarily on public companies and on the law of Delaware, the leading situs of incorporation in the United States for public companies. ${ }^{2}$ I examine several types of conflict scenarios: self-dealing between the corporation itself and the director; indemnification; directors' pursuit of business opportunities related to the corporation; and defenses to hostile take-over bids.

The legal treatment of self-interested transactions diverges more between the United States and the United Kingdom than one might predict, given common starting points. The United States and the United Kingdom share a legal heritage encompassing the common law and principles of equity. Corporation statutes in both countries do not supplant these principles. ${ }^{3}$ In both countries, corporation law is grounded in a necessary formalism that treats the corporation itself as a distinct legal entity that may incur obligations and possess rights separate from its owners. Likewise, although directors owe duties to the corporation itself, corporate law accords primacy to shareholders' interests.

In both countries, moreover, much business financing and investment is intermediated by capital markets, in contrast with financial systems predominantly organized around relatively activist financial institutions that themselves make and hold loans to business borrowers, and buy and hold equity investments in businesses. ${ }^{4}$ Against a backdrop of such similarity, differences in corporate law are especially significant when they affect the resolution of questions raised by common recurrences, such as transactions in which directors have a conflict of interest. The degree of divergence between U.S. and U.K. corporate law suggests that there is a much looser connection between the structure and operation of capital markets and the particular doctrines in un-

2. According to the most recent study, the degree of divergence among corporation statutes is not large. See William J. Carney, The Production of Corporate Law, 71 S. CAL. L. REV. 715 (1998).

3. See L.C.B. Gower, Some Contrasts Between British and American Corporation Law, 69 HARV. L. REV. 1369, 1370 (1956).

4. See Rafael la Porta et Al., Corporate Ownership Around the World 5 (NBER Working Paper 6625, June 1998). See generally MARK J. RoE, STRONG MANAGERS, WeAK OWNERS: THE POLITICAL ROOTS OF AMERICAN CORPORATE FINANCE (1994). 
derlying corporate law than is often assumed. ${ }^{5}$

Three types of divergence between U.S. and U.K. corporate law are particularly noticeable. First, the rules applicable to shareholder voting, as well as the function served by it, are different. In the United States, mandatory statutory rules have the effect of requiring that a substantial number of shareholders be given the opportunity to vote at periodic intervals on the initial election and subsequent reelection of directors. ${ }^{6}$ Corporate law in the United Kingdom, in contrast, relegates these matters to provisions in the corporation's articles, but by statute in the United Kingdom, shareholder approval by vote is requisite to validate a range of transactions in which directors have conflicts. ${ }^{7}$ Current U.K. corporate law is thus mandatory in contexts when U.S. corporate law is not, while U.K. law permits articles of the corporation to structure the most basic architecture for the relationship between shareholders and directors. These contrasts make relevant the contrasting demographics of shareholding in each country as well as contrasts in the composition of boards of directors.

Second, in the United States, statutes and cases invest in disinterested directors a considerable measure of discretion to assess the merits of conflict transactions and to determine in good faith whether and on what terms to bind the corporation to any such transaction. The role ascribed to the disinterested director unifies what are often treated as distinct doctrines, involving self-dealing transactions, corporate opportunities, and defenses to hostile take-over bids. The significance that U.S. law ascribes to the disinterested director's role makes it important to define its boundaries and to evaluate its credibility as an institution for discretionary decisionmaking internal to the corporation. An inevitable question is whether or under what circumstances disinterested directors are appropriately accountable to the interests of the corporation's shareholders. In contrast, the disinterested director, as distinct from the selfinterested director, does not figure in the picture of current U.K. law surveyed in the Consultation Paper, nor is the disinterested director cast as a favored player in the reforms discussed by the Commissions. ${ }^{8}$ U.K. law allocates authority to make discretionary decisions about questions implicated by directors' conflicts elsewhere-within the corporation to shareholders, and to decisionmakers external to the corporation itself.

Third, the United States and the United Kingdom diverge in the style and structure of corporate legislation and in the assumptions reflected in legislation regarding the likelihood of litigation. As noted above, U.K. corporate law permits a corporation's articles to prescribe rules on matters that, in the United States, are addressed in mandatory fashion in corporation statutes. It would nonetheless be a mistake to think that, on balance, U.K. corporate law is more

5. Cf. Frank H. Easterbrook, International Corporate Differences: Markets or Law?, 9 J. APP. CORP. FIN. 23 (1997) (characterizing law as an output of the drive toward economic efficiency).

6. See Companies (Tables A-F) Regulations 1985, S1 1985/805 ("Table A") regs. 40 \& 73 [hereinafter 1985 Regulations].

7. See, e.g., Companies Act, 1985, ch. 6, $\S \S 315,322$.

8. See CONSUltation PAPER, supra note 1, II II 4.197-.199. 
permissive or "contractualist," because such a characterization ignores the content and flavor of Part X of the Companies Act 1985. ${ }^{9}$ Much that Part X prohibits for U.K. corporations, or that it deals with in nonprohibitory but very detailed provisions, is in U.S. statutes swept within broad grants of discretion to directors. Accompanying the discretion is a likelihood of litigation challenging transactions that appear to be problematic. In the United Kingdom, by contrast, litigation appears to be more a fortuitous occurrence than one that is predictable.

Specifics aside for a moment, consider as a starting point a visual metaphor that illustrates the most striking disparity. Imagine a painting with a scenic background dominated in its foreground by a portrait of an individual person. Like the portrait, the independent director-strengths, weaknesses, constraints, and credibility-dominates the U.S. landscape, figuring prominently in statutes, cases, and academic commentary. The same landscape with the portrait removed is, in contrast, the image of corporate law in the United Kingdom that emerges from the Consultation Paper.

\section{CORPORATE DEMOGRAPHICS}

Directors do not act in isolation; as the Consultation Paper observes, they are "mutually interdependent" with shareholders, who "rely on directors to manage the enterprise competently, without taking personal benefits, loyally and on the basis that so far as practicable shareholders are kept in the picture about any matter which is relevant to them." ${ }^{10}$ Directors, in turn, rely on shareholders "to maintain their investment in the company and exercise their powers in respect of decision-making reserved to them in a favorable manner." 11 Corporate law does not, of course, treat directors' reliance identically with that of shareholders. The legally enforceable duties of directors underpin shareholders' reliance, while directors' reliance is grounded in optimistic, but unenforceable expectations of shareholder support.

The extent to which share-ownership is widely dispersed or concentrated, as well as its composition as between individuals and institutions, defines much of

9. This contrast calls into question the accuracy of the claim that in responding to a corporate governance crisis, while U.S. lawmakers might "pass a new law or regulation," the U.K. response would be "a blue-ribbon committee that recommends changes in current practice," typically mild changes in light of the nature of the committee process. Bernard S. Black \& John C. Coffee, Jr., Hail Brittania?: Institutional Investor Behavior Under Limited Regulation, 92 MiCH. L. REV. 1997, 2023 (1994). As the Law Commissions explain, Part X reflects the legislative response of successive Parliaments to scandals and other perceived instances of slippage in corporate governance practices. See CONSULTATION PAPER, supra note 1, III 1.9-.10. In general, though, extra-governmental responses to perceived problems appear to play a distinctive and significant role in the reform of corporate governance in the United Kingdom. See, e.g., Jayne W. Barnard, The Hampel Committee Report: A Transatlantic Critique, 19 COMPANY LAW. 110, 112 (1998) ("[T]o see British business leaders pursuing these objectives voluntarily — or at least to be moving in the right direction-is impressive and seems almost Victorian in its uprightness.").

10. CONSUltation PAPER, supra note 1, II 2.12.

11. Id. 
the texture of the interdependence between directors and shareholders. Directors are more likely to be responsive to the expectations of large shareholders and large consolidated groups of shareholders than to the expectationshowever determined or expressed-of a diffused and widely dispersed group. To begin with, large holders are better able to formulate and state expectations.

Though in both the United States and the United Kingdom much business financing and investment are intermediated by capital markets, patterns of share-ownership differ in the two countries. Institutions in the United Kingdom currently hold about sixty percent of shares in listed U.K. companies; individuals hold half of the remainder, while non-U.K. institutions hold the other half. ${ }^{12}$ Fund managers, appointed by trustees of U.K. pension schemes, likely have the power to sell over two-thirds of all listed U.K. equities. ${ }^{13}$ In the United States, direct individual ownership of shares is much higher than in the United Kingdom. However, as of 1997, institutional ownership accounted for $47.7 \%$ of outstanding equities, representing a dramatic increase from the $7.2 \%$ of equities held by institutions in $1950 .{ }^{14}$ Patterns vary among markets and industry cohorts. For example, individual investors are the dominant trading force in some market sectors, such as technology stocks. ${ }^{15}$ That individuals dominate trading activity does not necessarily mean that they dominate ownership, however. It is also helpful to distinguish among types of individual holders. In the NASDAQ market, which includes many technology-based companies, institutions own about half the outstanding holdings based on market value, directors of listed companies own about a quarter, and other "individuals" own the remaining quarter. ${ }^{16}$

An additional point of contrast is the degree to which institutional holdings are concentrated. Institutional ownership is generally believed to be much more concentrated in the United Kingdom; the twenty-five largest institutions reportedly own an absolute majority of stock in many companies. ${ }^{17}$ United Kingdom institutions have long been able to communicate and coordinate in ways facilitated by geographical concentration in the United Kingdom but inhibited by geographical dispersion and regulatory barriers in the United

12. See Committee on Corporate Governance, Final Report II 5.1 (1998) (Sir Ronald Hampel, chair) [hereinafter HAMPEL REPORT].

13. See Geof P. StApledon, Institutional Shareholders And Corporate Governance 48-49 (1996).

14. See New York Stock Exchange, 1997 FAct Book 61-62 (1998). But from 1992-95, the number of individual shareholders holding stock directly declined from 29.2 million to 27.4 million, a decline offset by the 3.3 million increase in the number of shareholders holding stock directly or through an equity mutual fund. See New York StOck EXCHANGE, SHAREOWNership 1998, 10 (1998).

15. Greg Ip, Individuals' Role in Stock Market Grows as the Influence of Institutions Declines, WALl ST. J., Nov. 16, 1998, at C1.

16. See NASDAQ StOCK MARKeT, 1996 FACT BoOK \& COMPANY DireCTORY 29 (1996). The NASDAQ market attracts $85 \%$ of initial public offerings in the United States. See id. at 1 . In dollar volume of trading, it is the second largest equity market in the United States. NASDAQ's dollar volume in 1995 trading was \$2,398,214 million compared with \$3,082,916 million on the New York Stock Exchange. See id. at 8.

17. See Black \& Coffee, supra note 9, at 2002. 
States. ${ }^{18}$ Some regulatory barriers in the United States have weakened, but institutions remain more diffused as owners than are institutional holders in the United Kingdom. Only relatively recently have U.S. institutions coalesced and intervened to compel changes in management. ${ }^{19}$

Patterns in board composition have long diverged between public companies in the United States and those in the United Kingdom as well, although the degree of divergence is narrowing. Boards in the United Kingdom have historically included fewer members who were not also officers of the corporation. The Hampel Committee reported in 1998 that, in large companies, boards often have "roughly equal numbers" of executive and non-executive directors, while small listed companies "tend to have a majority of executive directors." "In the United States, by contrast, "outside" (non-executive) directors predominate on the boards of public companies. In a 1998 study, the average board had two "inside" (executive) directors and nine outside directors. ${ }^{21}$ Moreover, the practices of using an audit committee $e^{22}$ and a compensation committee ${ }^{23}$ comprised of outside directors are well-established norms for U.S. public companies.

These developments in the United States make it unsurprising that "management" might not always be viewed as a unitary force and that, as more fully explored below, corporate law might differentiate functions between a corporation's outside directors and its operational managers. To be sure, being an "outside" director is not synonymous with "disinterested" as to a particular decision. On many of the points addressed in the Consultation Paper, U.S. corporate law invests decisionmaking discretion in disinterested directors who are often, but not always, "outside" directors.

\section{III}

\section{CORPORATE LAW AND CORPORATE GOVERNANCE}

The scope of the Consultation Paper does not encompass all aspects of corporate law that are generally relevant to the relationships between directors and shareholders. Nonetheless, corporate law does not address directors' conflict transactions in isolation. Therefore, contrasts between corporate law in

18. See id.

19. See Brian R. ChefFins, COMPANy LAw: TheOry, StruCture, ANd Operation 617-39 (1997). It is important not to overstate the significance of regulatory barriers to divergent governance structures. For example, although regulation did not constrain the governance role of U.K. banks as it did U.S. banks, corporate governance in the United Kingdom is not dominated by banks as it is in Germany. See Roberta Romano, A Cautionary Note on Drawing Lessons from Comparative Corporate Law, 102 YALE L.J. 2021, 2028 (1993).

20. HAMPEL REPORT, supra note 12, II 3.14.

21. See Korn/FERry INT'L, 25TH ANNUAL BOARD OF DiRECTORS SURVEY 14 (1998).

22. See AMERICAN LAW INSTITUTE, PRINCIPLES OF CORPORATE GOVERNANCE: ANALYSIS AND RECOMMENDATIONS $\S 3.05 \mathrm{cmt}$. a (1994) (noting that the New York Stock Exchange requires listed companies to establish and maintain an audit committee comprised of directors who are independent of management and free of any relationship that would interfere with the exercise of independent judgment).

23. See id. $\S 3 \mathrm{~A} .05 \mathrm{cmt}$. a (reporting the widespread practice in public companies of employing a compensation committee comprised entirely of outside directors). 
the United States and the United Kingdom, albeit on points not addressed in the Consultation Paper, are relevant.

In two basic respects, corporate law in the United States mandatorily prescribes answers to questions left in the United Kingdom to resolution in the company's articles. First, U.S. corporation statutes specify a mandatory minimum of shares - at least a third - that must be present in person or by proxy at the corporation's annual meeting to constitute a valid quorum. ${ }^{24}$ In a corporation with widely dispersed shareholding, the mandatory minimum quorum typically necessitates the solicitation of proxies by the corporation's incumbent directors. It is thus not feasible for incumbent directors to rely on a combination of shareholder inertia and a low quorum set in the company's articles to assure their reelection. The U.K. statute does not prescribe any minimum quorum, and it is U.K. practice to specify a very small quorum in the articles. The Hampel Committee reports that fewer than forty percent of shares were voted in the last five years. ${ }^{26}$

Second, U.S. corporation statutes specify a maximum term-most typically three years-for which a director may be elected. ${ }^{27}$ The U.K. statute does not impose a cap on directors' terms, although Section 319 of the Companies Act 1985 requires shareholder approval for directors' employment contracts that exceed five years in duration. ${ }^{28}$ The Hampel Committee reports and endorses institutional investors' expectations that directors submit to reelection at "regular intervals of no more than three years," recommending as well that biographical information be provided to enable shareholders to make informed decisions. $^{29}$ In contrast, in the United States, the federal regulation of proxy solicitations incident to annual meetings has long mandated the provision of such information. ${ }^{30}$ Indeed, securities regulation in the United States attempts to assure that beneficial holders of shares receive proxy material rather than

24. See, e.g., DEL. CODE ANN. tit. 8, § 216 (1998) (noting that in no event shall a quorum consist of fewer than one-third of shares entitled to vote); MODEL BUS. CORP. ACT $\S 7.27$ (a) (articles may require a quorum greater than a simple majority of votes entitled to be cast).

25. See Paul L. Davies, Gower's Principles of Modern COMPANy LaW 584 (6th ed. 1997). The default set in Table A, applicable unless the company's articles prescribe otherwise, is a twomember quorum. See 1985 Regulations, supra note 6, Table A, reg. 40.

26. See Hampel Report, supra note 12, II 5.7. As of the early 1990 s, usually fewer than $15 \%$ of shares were voted at annual meetings. See Jonathan Charkham, KeEPING Good Company 295 (1994). This data likely reflects the lack of any mandatory requirement that U.K. institutions vote shares that they hold as fiduciaries for others, comparable to the expectation that U.S. pension fund managers exercise their proxy-voting power. See Barnard, supra note 9, at 115.

27. See, e.g., DEL. CODE ANN. tit. 8, § 141(d) (1998); MODEl Bus. CORP. ACT $§ 8.06$ (staggeredterm statutes).

28. This limit, by definition, applies only to directors who also have an employment relationship with the corporation.

29. HAMPEL REPORT, supra note 12, II 3.21. The default set in Table A is that one-third of the corporation's directors should retire and stand for reelection annually. See 1985 Regulations, supra note 6, Table A, reg. 73. The Hampel Committee's recommendation suggests either that some companies with Table A articles do not comply with them, or that some articles do not adopt the Table A default.

30. See Proxy Rule 14a-3 \& Schedule 14A, item 7. 
leaving voting decisions to registered or nominee holders alone. ${ }^{31}$

In these basic respects, corporate law speaking in a mandatory voice plays a larger role in structuring relationships between shareholders and directors in the United States than in the United Kingdom. United States law, as we shall shortly see, vests in disinterested directors the capacity to exercise discretion on questions that U.K. law reserves to shareholders. The mandatory rules just surveyed, though, undergird the directors' position with an assured frequency of occasions at which a relatively large proportion of shareholders affirmatively vote to continue the director's service. ${ }^{32}$ This assurance may appear less important if the number of holders of shares is smaller, or if relatively large holdings are common and are not generally used toward ends that disadvantage smaller holders.

\section{IV}

\section{STATUTORY TREATMENT OF DISINTERESTED DIRECTORS}

As in the United Kingdom, the operative content of corporate law in the United States is a combination of legislation and cases. State corporation statutes vary in the extent to which they attempt to codify directors' duties. In Delaware, case law plays a large role in defining the limits imposed on directors' fiduciary position in the exercise of powers they hold by virtue of their position. The Model Business Corporation Act, in contrast, codifies directors' duties; however, its appearance of certainty is belied by the open texture of its language, which includes terms like "good faith," "reasonably," and "under similar circumstances." $" 33$

For our immediate purposes, these differences matter less than the fact that corporation statutes in the United States specify the types of decisions that may be made by disinterested directors. In particular, statutes define a decisionmaking role for disinterested directors with regard to self-dealing transactions

31. See IV Louis Loss \& Joel Seligman, Securities Regulation 1943 (3d ed. 1989). In contrast, the Hampel Committee characterizes nominee holding as a circumstance that "deprives the investors concerned of the right to vote and receive company information unless some special arrangement is made." HAMPEL REPORT, supra note 12, II 5.25. Many custodians that use nominee holders "seek to pass company information to investors for reasons of good service and good practice, and will actively arrange for investors' views to be reflected in a proxy vote." RICHARD SMERDON, A PRACTICAL GUide to CORPORATE GOVERnANCE 209 (1998). Statutory reinforcement for these practices is under consideration by government departments.

32. At initial glance, shareholders in U.K. companies are assured the right to remove directors without cause by Companies Act 1985, $\S 303$, whereas in a Delaware corporation in which the board is classified into staggered terms, see DEL. CODE ANN. tit. 8, § 141(d) (1998), directors may be removed only for cause unless the certificate of incorporation affirmatively provides otherwise, see id. $\S$ 141(k)(1). This difference is less than immediately meets the eye, for in Bushell v. Faith, 1 App. Cas. 1099 (1970), the House of Lords upheld a "golden share" issued to a director that assured him of the power to outvote other shareholders when his removal was at issue. The listing requirements for a listing on the U.K. stock exchange disallow an arrangement comparable to that in Bushell v. Faith. See Gerard McCormack, Institutional Shareholders and the Promotion of Good Corporate Governance, in THE REALM OF COMPANY LAW: A COLLECTION OF PAPERS IN HONOUR OF PROFESSOR LEONARD SEALY 131, 141 (Barry A.K. Rider ed., 1998).

33. MODEL Bus. CORP. ACT $\$ 8.30$. 
and indemnification.

\section{A. Self-dealing Transactions}

Statutory treatments of self-dealing are not identical among jurisdictions, but the Delaware provision is illustrative. ${ }^{34}$ Section 144 of the Delaware General Corporation Law applies to a contract or transaction between a corporation and one or more of its directors or officers, as well as to a contract or transaction between a corporation and another organization in which one or more directors or officers of the corporation are also directors or officers of the organization or have a financial interest in the transaction. Section 144 provides that such a contract or transaction shall not be void or voidable as a consequence of the director's or officer's interest, or due to his presence or participation in a meeting of the board or a committee at which the contract or transaction is authorized, if any of three conditions is satisfied:

(1) The material facts as to the director's or officer's relationship or interest and as to the contract or transaction are disclosed or are known to the board of directors or the committee, and the board or committee in good faith authorizes the contract or tran saction by the affirmative votes of a majority of the disinterested directors, even though the disinterested directors be less than a quorum; or

(2) The material facts as to the director's or officer's relationship or interest and as to the contract or transaction are disclosed or are known to the shareholders entitled to vote thereon, and the contract or transaction is specifically approved in good faith by vote of the shareholders; or

(3) The contract or transaction is fair as to the corporation as of the time it is authorized, approved or ratified, by the board of directors, a committee or the shareholders. ${ }^{35}$

Section 144 and its counterparts in other states are often characterized as "safe harbor" provisions because they shelter the transaction from jeopardy. Safe harbor provisions differ from the content of Part X in style and structure as well as operative content: They are drawn broadly and encompass situations dealt with individually in separate sections in Part X. Safe harbor provisions succinctly delineate authority, as well as the circumstances that legitimate its exercise by a particular decisionmaker. ${ }^{37}$

34. One point of difference is simply the level of detail specified by the statute itself. The Delaware provision is much shorter and stated in more general terms than its counterpart in the Model Business Corporation Act. Compare Del. CodE ANN. tit. 8, § 144 (1998) with MOdEL Bus. CoRP. ACT $\S 8.60-.63$.

35. Del. Code ANN. tit. 8, § 144(a)(1)-(3) (1998).

36. As the third option in the tripartite Delaware statute contemplates litigation in which a court evaluates the merits of the transaction, it affords a less snug harbor than the other two options.

37. One evident difference among statutes is the extent to which the statute appears to foreclose the possibility of any judicial scrutiny. The Delaware statute requires that approval by disinterested directors be "in good faith," and Delaware cases articulating the elements of the business judgment rule require that directors act with due care in an informed manner. See Aronson v. Lewis, 473 A.2d 805, 812 (Del. 1984). The counterpart safe harbor provision in the Model Business Corporation Act, section 8.62, does not itself require that disinterested directors act in good faith and with due care. Commentary to a prior section, section 8.61(b), states that the board's action in this context must comply with the general standards stated in section 8.30(a) for all directors' actions, which require that di- 
Moreover, Section 330 in Part X categorically prohibits loans and guarantees on behalf of directors and persons connected to them-transactions that would be within the scope of Delaware's safe harbor provision. As it happens, the preceding section in the Delaware statute, section 143, specifically authorizes a corporation to lend money to, or guarantee obligations incurred by, any employee or officer, including one who is also a director, whenever "in the judgment of the directors" such transaction "may reasonably be expected to benefit the corporation." In this connection, it is striking that the chapter of the Consultation Paper devoted to "economic considerations" observes that "it is difficult to envisage circumstances where a loan from the company, as opposed to one from a third party, would be justified. ${ }^{39}$ The Delaware statute leaves to the assessment of directors whether such circumstances are present and assumes that creditors' interests are sufficiently protected by the risk of liability assumed by directors whose judgment does not meet the statutory standard or whose action otherwise constitutes a breach of their duties of care and loyalty.

Unlike Part X, safe harbor provisions authorize a decisionmaking role for disinterested directors, even when their number is insufficient to constitute a quorum. Safe harbor provisions also contemplate that a court may review the substantive merits, or fairness, of the transaction. In both respects, the statutory provisions reflect prior evolution in cases from an initial position, held through the last quarter of the nineteenth century, making any contract between a director and the corporation voidable at the corporation's insistence. ${ }^{40}$ In his study of this evolution, Harold Marsh reports that "one searches in vain in the decided cases for a reasoned defense of this change in legal philosophy" to permit the transaction to be insulated from challenge by a majority of disinterested directors. ${ }^{41}$ Judicial review to ascertain the fairness of transactions, as an alternative to approval by disinterested directors, appears to surface in the cases by $1960 .^{42}$ The status of shareholder ratification is less significant because it is not needed if the court finds the transaction to be fair. ${ }^{43}$ In any event, unlike sui juris beneficiaries of a trust negotiating with their trustee, shareholders are limited to accepting or rejecting a transaction negotiated by the interested

rectors act with care, in good faith, and in a manner reasonably believed to be in the corporation's best interests. See also AMERICAN LAW INSTITUTE, supra note 22, § 5.02 reporter's note 13.

38. Id. $\S 143$. The wisdom of permitting such loans has been questioned. See Jayne W. Barnard, Corporate Loans to Directors and Officers: Every Business Now a Bank?,1988 WIS. L. REV. 237. The District of Columbia is, as of this date, the sole remaining U.S. jurisdiction categorically to prohibit loans to directors. See D.C. CODE ANN. § 29-304(6) (1997-98) (corporation lacks the power to make a loan to its own director).

39. CONSUltation PAPER, supra note 1 , II 3.55 .

40. See Harold Marsh, Jr., Are Directors Trustees? Conflict of Interest and Corporate Morality, 22 BUS. LAW. 35, 36 (1966).

41. Id. at 40.

42. See id. at $43-44$.

43. It is telling that under current Delaware law, the legal consequences of attempted shareholder ratification are not clear. See Mary A. Jacobson, Note, Interested Director Transactions and the (Equivocal) Effects of Shareholder Ratification, 21 DEL. J. CORP. L. 981 (1996). 
directors, who had no disinterested representative at the bargaining table and were not present at the table themselves. ${ }^{44}$ Of course, the knowledge that shareholders must approve a transaction may shape the evolution of the transaction, especially when the shareholders are believed to be astute and vigilant. But in most instances, shareholders will not participate directly either in structuring the transaction or in making the nuanced assessment of tradeoffs that is integral to any bargaining process. In short, courts in the United States may have acquiesced in the determinations of disinterested directors because such directors are, at least in theory, capable of representing the shareholders' interests in shaping the terms of the transaction. And courts may have believed that substantive judicial review is more likely to detect problematic transactions than is submission to shareholders.

Delaware cases have evolved a set of distinctions that define thresholds for substantive judicial review. Whether the court will review the merits of the directors' decision depends on whether the transaction involves simply a director or, additionally, a shareholder with voting control over the corporation. Under a safe harbor provision, in a transaction involving a director or officer, a majority of disinterested directors may bind the corporation to the transaction if the interested director or officer discloses material facts and if the disinterested directors act in good faith. If these conditions are satisfied, Delaware cases treat the disinterested directors' decision as a business judgment, which means that the court does not review the merits of the decision.

An interested director has a duty to be candid, which requires disclosure of "all material information relevant to corporate decisions from which they may derive a personal benefit." If a director does not disclose an interest to the board, the corporation has a range of remedies available to it, including the assertion of an ownership interest in property the director has acquired through the transaction. ${ }^{47}$ If the director breaches the duty of candor, it is not likely to be a defense for the director that he paid a price fair at the time of the transaction for property acquired from the corporation because, in Delaware, the test for fairness is "entire fairness," which encompasses fair dealing as well as fair price. ${ }^{48}$ If the director discloses an interest to the board, the focal points in litigation will be whether the disclosure was sufficient to enable the disinterested directors to assess the corporation's interests, ${ }^{49}$ and whether the disinterested directors acted in an informed manner and in good faith. ${ }^{50}$ Disinterested directors who are adequately informed and who approve a transaction in good faith

\footnotetext{
44. See Marsh, supra note 40, at 49.

45. See Marciano v. Nakash, 535 A.2d 400, 405 n.3 (Del. 1987).

46. Mills Acq. Co. v. Macmillan Inc., 559 A.2d 1261, 1280 (Del. 1989).

47. See State ex rel. Hayes Oyster Co. v. Keypoint Oyster Co., 391 P.2d 979 (Wash. 1964).

48. See id. 1918).

49. The classic illustration is Globe Woolen Co. v. Utica Gas \& Elec. Co., 121 N.E. 378 (N.Y.

50. For a recent illustration, see In re The Walt Disney Co., No. 15452, 1998 WL 731587 (Del. Ch. Oct. 7, 1998).
} 
are protected from personal liability by the business judgment rule, which, when applicable, forecloses substantive judicial review of the merits of the transaction itself.

In contrast, if the contract or transaction involves a controlling shareholder-who is likely to have representatives on the corporation's board-the court examines the substantive fairness of the transaction to the corporation and its noncontrolling shareholders. In Kahn v. Tremont Corp., ${ }^{51}$ the Delaware Supreme Court recently clarified the law on this point. When directors evaluate a transaction with a controlling shareholder, the reality is that the shareholder "will continue to dominate the company regardless of the outcome of the transaction." 52 As a result, "those who pass upon the propriety of the transaction might perceive that disapproval may result in retaliation by the controlling shareholder," even when the directors who approve the transaction are otherwise free of ties to the controlling shareholder. ${ }^{53}$ Indeed, a "risk of retaliation" is present if the noncontrolling shareholders pass upon the transaction, given the controlling shareholder's power to elect directors with authority to make determinations on matters like dividends. ${ }^{54}$

Statutory safe harbor provisions are different in scope and operation from section 317 of the Companies Act 1985. Section 317 requires directors to disclose to the board any interests they may have in present or proposed contracts with the corporation. A director who fails to comply with section 317 is subject to a fine. Section 317 does not vest discretion in the board's disinterested directors to determine whether the contract is fair to the corporation. It operates as an adjunct to the general law, which determines when a self-dealing transaction is voidable. ${ }^{55}$

Statutory safe harbor provisions also differ in operation from sections 32022 of the Companies Act 1985, which require shareholder approval in general meetings before a director's purchase from or sale to the corporation of substantial noncash assets. ${ }^{56}$ Absent prior approval, the transaction is voidable by the corporation unless shareholders affirm it in general meeting, restitution is no longer possible, or bona fide third-party rights would be adversely affected by unwinding the transaction. In any event, absent prior shareholder approval, the director is liable to account to the corporation for profit realized and to compensate it for loss.

The mandatory shareholder approval requirements imposed by U.K. company law likely have varied consequences. Consider first the possible impact

\footnotetext{
51. 694 A.2d 422, 428 (Del. 1997).

52. $I d$.

53. Id.

54. See Citron v. E.I. Du Pont de Nemours \& Co., 584 A.2d 490, 502 (Del. Ch. 1990).

55. CONSUlTAtion PAPER, supra note 12, II 4.78.

56. The treatment of such transactions in Table $\mathrm{A}$ is silent on whether shareholder approval is requisite. See Table A, supra note 6, reg. 85-86. Given the statutory mandate imposed by sections 320-22, the contents of Table A appear to be lagging.

57. See Companies Act 1985, ch. 6, § 322(3).
} 
on self-dealing transactions, and second the possible impact upon, or relationship to, the demographics of shareholding. The requirement might result in fewer self-dealing transactions, or in transactions whose proposed terms reflect awareness that a shareholder vote will be necessary. In considering these possibilities, the cost of obtaining shareholder approval is relevant. If shareholding in a corporation is widely dispersed, and if shareholder approval for the selfdealing requires a separate communication to shareholders followed by a meeting, the cost will be greater than in a corporation with less widely dispersed ownership. Alternatively, this prospect might make it more attractive to corporate directors to enlist large shareholders to reduce the cost of obtaining consent to self-deal, ${ }^{58}$ or it might reduce the number of self-dealing transactions if directors find the benefits of wider-cast shareholding outweigh the foregone advantages of self-dealing. A further possibility is that the incidence of selfdealing and the degree of dispersion in shareholding might be unrelated, which could be the case if the marginal costs of submission to shareholders are not so great, or if directors are uninhibited in imposing such costs on companies. This possibility is supported by the belief that U.K. shareholders, institutional as well as individual, tend toward unengagement. ${ }^{59}$ Finally, the prospect that a self-dealing transaction would be assessed by a relatively small number of sophisticated investors may itself inhibit self-dealing or encourage moderation in the transaction's proponents.

The Consultation Paper expressly considers, and provisionally rejects, a shift toward allocating discretion to disinterested directors to approve selfdealing transactions. Acknowledging that convenience and cost savings would follow such a shift, the Consultation Paper relies on three objections: (1) "Beneficial disclosure to shareholders" would be lost; (2) the concept of independence would require definition; and (3) it would be difficult to assure "that the independent directors had in fact decided the matter in an independent way." $" 60$

Resolving these issues in a satisfactory manner is crucial to the effectiveness and credibility of a corporate governance system. The response characteristic of the United States may not be feasible in the United Kingdom. The fundamental point is that corporation statutes do not operate in a legal or institutional vacuum. Mandatory disclosure requirements, imposed by federal securities regulation, supplement the operation of corporate law itself in the United States. A self-dealing transaction in a public company must be disclosed in the corporation's annual report in compliance with requirements imposed by the

58. Professor Sealy noted that mandatory submission to shareholders would open the prospect that "companies will shrink from the expense, and cultivate the institutional investors." L.S. SEALY, COMPANY LAW AND COMMERCIAL REALITY 29 (1984). An empirical test for Professor Sealy's argument would examine shifts in shareholding patterns in the wake of Part X's requirements.

59. See CHARKHAM, supra note 26, at 335 ("The reality is that many shareholders do not see their interests, or those on whose behalf they hold shares, being best served by taking any interest in or playing any part in corporate governance."). Relatively few U.K. shareholders vote, at all, and institutional shareholders are subject to no legal mandate to vote. See supra text accompanying note 26.

60. CONSUltation PAPER, supra note 1, II II 4.197-.199. 
Securities and Exchange Commission (the "SEC"). ${ }^{61}$ Although the annual report in which the disclosure is made is not distributed to shareholders, who receive a shorter version, the report must be filed with the SEC and is a generally accessible public document. Indeed, the report is available without charge and can be obtained very rapidly by all who search the SEC's public database and filing system, EDGAR. ${ }^{62}$ Disclosures of conflict-of-interest transactions are trolled with keen interest by financial journalists, institutional investors, and likely by entrepreneurial lawyers who represent shareholders in litigation. Moreover, the threat of a shareholder lawsuit, brought derivatively on behalf of the corporation, is a serious prospect in the United States in connection with aggressively structured self-dealing transactions. The occurrence of such suits has produced a robust body of cases defining circumstances in which directors are likely to have acted independently, as well as a demonstrable judicial capacity to examine the circumstances specific to a particular transaction. ${ }^{63}$

In short, in the United States, safe harbor provisions in corporation statutes vest discretion in disinterested directors to commit the corporation to conflict transactions. Directors must exercise the discretion in good faith and an informed manner to be insulated from personal liability. Judicial review of the substantive merits of self-dealing transactions is available. Transactions with controlling shareholders are subject to judicial review on their merits, as are directors' self-dealing transactions in the absence of approval by disinterested directors or shareholders. These doctrines create incentives to install credible institutions for decisionmaking at the board level by rewarding boards with disinterested members through the insulation afforded by the business judgment rule. To the extent U.S. corporate law has enhanced the expectations applicable to directors by articulating specific functions that directors must fulfill, the significance of the disinterested director's role has been enhanced as well. Moreover, as a consequence of the rich informational environment in the United States, ${ }^{64}$ the occurrence of a self-dealing transaction of any significant magnitude in a public corporation is readily ascertainable. Shareholder litigation challenging the terms of such transactions and the circumstances under which directors approve them occurs with some frequency. In contrast with the United Kingdom, different mechanisms of accountability are at work in the United States. In the stead of direct shareholder approval through a vote, as is

61. See Regulation S-K, item 404, 17 C.F.R. $§ 229.404$ (1999) (requiring disclosure of any transaction involving an amount in excess of $\$ 60,000$ in which a direct or indirect material interest is held by a director, a nominee for election as director, a record or beneficial holder known to the company to own more than five percent of any class of voting securities, or by any member of the immediate family of such person).

62. EDGAR filings may be accessed through the SEC's website: $<$ http://www.sec.gov $>$.

63. For a discussion of recent cases illustrating such examination, see Grover C. Brown et al., Director and Advisor Disinterestedness and Independence under Delaware Law, 23 DEL. J. CORP. L. 1157 (1998).

64. The breadth of directors' duties of disclosure in the United States has been usefully contrasted with the U.K. position in John Lowry, Ratifying Directorial Wrongdoing-The Legal Fiction of Shareholder Consent in England, in THE CORPORATE DIMENSION 161-77 (Barry A.K. Rider ed., 1998). 
required by much of Part X, and of Part X's categorical prohibition of specific transactions, is a set of more indirect mechanisms of accountability that may operate as a check on the exercise of discretion by disinterested directors.

Finally, U.S. corporation statutes do not themselves criminalize breaches of duty, as do selected provisions in Part X. Willful misrepresentations, as well as market manipulation and insider trading, are criminalized, but by the penalty provisions in federal and state securities regulation, not by corporate legislation itself. $^{65}$ In the absence of fraud, theft, or similar misconduct, the United States does not criminalize breaches of directors' duties.

\section{B. Indemnification and Exculpation}

Section 310 in the Companies Act 1985 renders invalid any provision in the corporate constitution or in a contract that indemnifies corporate officials against a breach of duty. In contrast, though subject to a number of qualifications, conditions, and exceptions, corporation statutes in the United States permit indemnification of directors and officers who have not succeeded in the defense of claims against them. Indemnification is a distinct concept from exculpation, which relieves an actor of liability. On the indemnity front, section 145 in the Delaware statute specifies the circumstances under which corporations have power to indemnify in connection with civil or criminal actions or investigations to which the proposed indemnitee was a party by reason of the person's connection to the corporation as its director, officer, employee, or agent, or by service in like capacity in another enterprise at the corporation's request. To be eligible for indemnification, the proposed indemnitee must have "acted in good faith and in a manner reasonably believed to be in or not opposed to the best interests of the corporation, and, with respect to any criminal action or proceeding, had no reasonable cause to believe such person's conduct was unlawful." $" 66$ In actions by or in the right of the corporation, indemnification is limited to attorneys' fees and other expenses, ${ }^{67}$ while in all other actions indemnification may also include fines, judgment amounts, and amounts paid in settlement. ${ }^{68}$ To the extent the proposed indemnitee's defense has been successful, indemnification is mandatory, as opposed to a discretionary exercise of the corporation's power to indemnify. ${ }^{69}$ The corporation may, however, oblige itself, by contract, bylaw, or resolution adopted by shareholders or directors, to exercise its power to indemnify. ${ }^{70}$

65. See, e.g., Securities Exchange Act of 1934, 15 U.S.C. § 78ff (1997).

66. DEL. CODE ANN. tit. 8, § 145(a) (1998).

67. See id. $\$ 145(\mathrm{~b})$.

68. See id. $\$ 145(\mathrm{a})$.

69. See id. $\S 145(c)$. Some statutes mandate indemnification only when the proposed indemnitee has been "wholly successful," see MODEL BUS. CORP. ACT $\$ 8.52$, or only when the successful defense has been "on the merits," see CAL. CORP. CODE § 317(d) (West 1999).

70. See DEL. CODE ANN. tit. 8, § 145(f) (1998). The corporation may not bind itself to indemnify beyond the extent of its statutory power to indemnify, which subjects contracts to indemnify to the statutory standards applicable to the indemnitee's conduct. See Waltuch v. Conticommodity Services, Inc., 88 F.3d 87 (2d Cir. 1996) (applying Delaware law). 
The structure of section 145 requires a determination that the proposed indemnitee's conduct met the prescribed standards for eligibility, coupled with a decision to indemnify if the prescribed standard is met. Under section 145(d), the determination, with one exception, may be made by a majority vote of directors not party to the action, by a committee designated by such directors, by stockholders, or by independent legal counsel appointed by directors. If the action is by or in the right of the corporation, and the proposed indemnitee has been adjudged to be liable, indemnification may be made only if the court determines that the person is "fairly and reasonably" entitled to be indemnified. ${ }^{71}$

Indemnification is similar to exculpation because both reduce the financial risks and burdens otherwise borne by directors. Nonetheless, the two doctrines do not operate identically. The power to indemnify is the power to expend corporate assets to benefit a director, whereas the power to exculpate is the power to release, or preclude the creation of, an underlying liability. It is helpful to examine indemnification and exculpation in connection with the business judgment rule, itself examined in the Consultation Paper. ${ }^{72}$ Since the mid1980 s, corporation statutes in the United States have permitted corporations to exculpate directors from money damages for liability to the corporation or its shareholders arising from breaches of the duty of care, through provisions in the corporation's articles or certificate of incorporation. ${ }^{73}$ Exculpation thus applies more narrowly than does the power to indemnify because it implicates only breaches of the director's duty of care owed to the corporation or its shareholders. Moreover, a valid exculpatory provision does not create discretionary authority, as does the power to indemnify. The business judgment rule, likewise, is a doctrine that reduces risks otherwise borne by directors. When the business judgment rule applies, the court does not review the merits of a decision made by directors. The rule applies to a director who acted in good faith and with adequate information, and who was not interested in the transaction or other subject of the judgment. As formulated by Delaware cases, moreover, the rule creates a presumption that directors were disinterested and acted in good faith and with adequate information. ${ }^{74}$ A litigant challenging the directors' decision thus has the burden on whether the business judgment rule applies. The business judgment rule is comparable to exculpation because both, when applicable, preclude a finding of liability. Unlike indemnification, but like exculpation, the business judgment rule is not an institution that creates or confers discretion. In contrast, the power to indemnify enables a decisionmaker to consider specific circumstances that justify shifting to the corporation some-or all - of the financial costs incurred by a director, including settlement or judgment amounts and attorneys' fees.

71. DEL. CODE ANN. tit. 8, § 145(b) (1998).

72. CONSUltation PAPER, supra note 1, IIII 15.30-.41.

73. See, e.g., Del. CoDE ANN. tit. 8, § 102(b)(7) (1998). See generally Deborah A. DeMott, Limiting Directors' Liability, 66 WASH. U. L.Q. 295 (1988).

74. See Aronson v. Lewis, 473 A.2d 805 (Del. 1984). 
Nothing in the U.K. legislation authorizes a comparable discretionary determination by the corporation's disinterested directors. The U.K. structure allocates authority to the court and to the shareholders to relieve directors of liability, although not to indemnify against expenses. Section 727 of the Companies Act 1985 permits the court to relieve a director of liability in proceedings against him for negligence, default, breach of duty, or breach of trust if the court determines that the director has behaved "honestly and reasonably," notwithstanding the fact that he is or may be liable, and that the director should be excused from liability in light of all the circumstances. ${ }^{75}$ Apart from section 727 , to the extent shareholders have discretionary authority, it is to ratify the director's conduct, not to indemnify against the financial consequences of the breach. Ratification does not reach directors' breaches of duties owed to third parties, in contrast to the statutory powers to indemnify created by U.S. corporation statutes. Finally, as to some breaches of duty by directors, the U.K. statute also situates discretionary authority in the prosecutorial offices of the state. $^{76}$

To be sure, despite the prohibitory language in section 310, U.K. corporate legislation expressly permits corporations to purchase director and officer ("D\&O") insurance. ${ }^{77}$ The D\&O insurer, in the event of a claim by a director against the policy, evaluates whether the loss is covered by the policy or whether it is excluded. Typical language in the U.S. and U.K. policies excludes coverage when the claim arises from the insured's intentional misconduct and when the insured profited personally through the conduct. ${ }^{78}$ The U.K. legislation externalizes entirely to a third party - the insurer - the authority to evaluate concrete circumstances. The evaluation occurs in a contractually defined context in which the insurer has no discretion to deny coverage for a claim covered by the policy. Indemnification statutes, in contrast, create power and discretion to indemnify defendants whose defense has not succeeded.

\section{$\mathrm{V}$}

\section{THE COMMON LAW OF THE DISINTERESTED DIRECTOR}

Apart from statutory provisions, the role of the disinterested director is often at issue in U.S. cases involving self-interested actions taken by directors. The contrast with U.K. law is especially sharp in two contexts: (1) the individual pursuit of business opportunities related to the corporation, and (2) defensive actions in response to hostile takeover bids. In both contexts, U.S. law allocates significant decisionmaking discretion to disinterested directors although judicial oversight has a more expansive and substantive character when directors take action to defeat or forestall an unwelcome takeover bid.

\footnotetext{
75. See Companies Act 1985, ch. 6, § 727.

76. See, e.g., id. § 317.

77. See id. $\S 310(2)$ (as amended by Companies Act 1989, ch. 40, § 137(1)).

78. See CHEFFINS, supra note 19 , at 108 .
} 


\section{A. Corporate Opportunities}

The disinterested director's capacity to exercise discretion when other directors are conflicted is integral to understanding the major disparity between doctrine in the United States and its counterpart in the United Kingdom when a director pursues a business opportunity that is, one way or another, related to the corporation or to the director's position. Divergences among jurisdictions in the United States turn on the structure, style, and timing of disinterested directors' involvement. Directors in the United Kingdom are held to a strict duty to account for profits when they personally pursue a business opportunity related to the company's line of business. Only if disinterested directors formally consider the opportunity and reject it is an individual director free to take the opportunity personally. In Regal (Hastings) Ltd. v. Gulliver, the House of Lords required the disgorgement of profit made by directors upon the sale of shares because the shares were acquired by reason of their positions as directors, even though the company lacked the financial ability to buy the shares itself, the purchasing directors used their own money, and the purchasing directors' good faith was not in issue. ${ }^{79}$ In a later Privy Council decision, Queensland Mines Ltd. v. Hudson, the director was not liable to account for profits made because the board previously "knew the facts, decided to renounce the company's interest in and assented" to the individual director's taking the opportunity at his own risk and for his own benefit. ${ }^{80}$ It is difficult to reconcile Queensland Mines with Regal (Hastings) without legitimating the corporation's disinterested directors as a discretionary decisionmaker within the corporation, a decisionmaker whose assent in good faith obviates the need to turn to the shareholders. As Robert Austin notes, though, the Privy Council in Queensland Mines did not explicitly identify a principle that explains why the directors could reduce the scope of a fellow director's fiduciary duty without the assent of a majority of shareholders, let alone the assent of all shareholders. ${ }^{81}$

Some U.S. jurisdictions would not protect the director who pursues such an opportunity individually unless, as in Queensland Mines, the director first presented the opportunity to the corporation's board, following which the board's disinterested members, making a collective decision, rejected the opportunity. ${ }^{82}$ The requirement of formal presentation recognizes that boards generally make decisions as a group, that group dynamics differ from individualized decisionmaking, and that formal presentation at a meeting facilitates both deliberation and the exchange of opinions among disinterested directors. ${ }^{83}$ In contrast, the

79. 1 Eng. Rep. 378 (1942); [1967] 2 App. Cas. 134.

80. (1978) 52 A.L.R. 379.

81. Robert P. Austin, Fiduciary Accountability for Business Opportunities, in EQUITY AND COMMERCIAL RELATIONSHIPS 141, 183 (Paul D. Finn ed., 1987).

82. This position is concisely stated in AMERICAN LAW INSTITUTE, supra note 22, § 5.05(a). Cases adopting this approach include Klinicki v. Lundgren, 695 P.2d 906 (Or. 1985) and Northeast Harbor Golf Club v. Harris, 661 A.2d 1146 (Me. 1995).

83. See Cellular Information Sys., Inc. v. Broz, 663 A.2d 1180, 1186 (Del. Ch. 1995), rev'd, 673 A.2d 148 (Del. 1996). 
most recent Delaware case of note, Broz v. Cellular Information Systems, Inc., explicitly rejected a requirement of formal presentation in favor of a more loosely formulated requirement of good faith on the part of the director who takes the opportunity individually. ${ }^{84}$ In $\mathrm{Broz}$, the opportunity was pursued by an outside director who, although he did not present it formally to the corporation's board, informed the corporation's CEO and other directors of his interest in the opportunity. Each told him that they believed the corporation itself-only recently emerged from a bankruptcy reorganization-would not be interested. To the Delaware Supreme Court, the key point was that the director did not take the opportunity surreptitiously. Commentators on Broz emphasize the substantive content of the court's approach and its focus on the director's good faith as opposed to whether the director formally presented the opportunity to the board. ${ }^{85}$

As Broz itself illustrates, though, disclosure to board members individually will not be credible-either to assure that the director acted in good faith or that the opportunity was handled consistently with the shareholders' interestsunless one makes assumptions about the likely behavior of the disinterested directors. That is, Broz reflects a court willing to assume that, even in the absence of a formal presentation and a formal meeting, disinterested directors will evaluate and react appropriately to information they receive from a fellow director, asking the necessary questions and bringing matters to the attention of other directors when circumstances so require. The institution of the disinterested director is assumed in Broz to be sufficiently robust that a director approached individually will be no less focused on the corporation's best interests than the director would be in considering the matter in the environment of a formal meeting. Jurisdictions that require formal presentation repose confidence in disinterested directors acting as a deliberative group, but perhaps doubt the reliability of one-by-one disclosures and assent.

In other settings, U.S. statutes and cases repose confidence in disinterested directors under circumstances that invite skepticism In shareholder derivative litigation, $\operatorname{cases}^{86}$ and statutes ${ }^{87}$ authorize the creation of a committee comprised of directors who did not benefit personally from the transaction impugned by the suit to evaluate whether maintaining the suit is in the corporation's best interests. Jurisdictions vary in the standard of judicial review applicable to a committee determination that the corporation's interests would not be best served by maintaining the suit. ${ }^{88}$ In contrast to directors asked to assess a self-

84. 673 A.2d 148 (Del. 1996); accord Ostrowski v. Avery, 703 A.2d 117 (Ct. 1997).

85. See John Lowry \& Rod Edmunds, The Corporate Opportunity Doctrine: The Shifting Boundaries of the Duty and its Remedies, 61 MOD. L. REV. 575 (1998). Another commentator emphasizes that information concerning the opportunity and the corporation's financial inability to capture it were common knowledge. See Eric Talley, Turning Servile Opportunities to Gold: A Strategic Analysis of the Corporate Opportunities Doctrine, 108 YALE L.J. 277, 322 (1998).

86. See, e.g., Auerbach v. Bennett, 393 N.E.2d 994 (N.Y. 1979); Zapata Corp. v. Maldonado, 430 A.2d 779 (Del. 1981).

87. See, e.g., MODEl Bus. CORP. ACT $§ 7.44$.

88. See Deborah A. DeMott, Shareholder Derivative Actions § 5:14-:23 (1987 \& 1998 
dealing transaction under a safe harbor statute, or directors asked to assess a colleague's pursuit of a business opportunity related to the corporation, directors on a litigation committee are asked to consider whether one of their colleagues should be subject to attack by an outsider, the plaintiff in the derivative suit. This scenario may presuppose a degree of detachment that few bear toward their colleagues. ${ }^{89}$ Contrasts with U.K. law have little importance because of the U.K. law's imposition of substantive and procedural barriers to shareholder litigation, points to which I will return below. It is nonetheless noteworthy that although U.K. precedents do not invest discretion in disinterested directors respecting shareholder derivative litigation, shareholders may be able to require that an action be discontinued. In Smith $v$. Croft, the plaintiffs sought recovery on behalf of the company of payments made ultra vires to the defendants, who held sixty-two percent of voting power in the company. The court held that a majority of the company's shareholders who were independent of the defendants could determine that the plaintiffs should not continue to prosecute the action. ${ }^{90}$ Smith v. Croft thus situates discretion in disinterested shareholders and does not address whether directors might credibly play a role in assessing the merits of derivative actions.

\section{B. Defenses to Hostile Takeover Bids}

Well beyond the scope of Part X and the Consultation Paper, directors' reactions to unwelcome takeover bids for many observers raise the most dramatic instance of conflict of interest. Assessing the overall import of U.S. law requires examining its application in this context as well. A sizable number of Delaware cases consider the circumstances under which the court should defer to the judgment of the corporation's outside directors that the best interests of the corporation warrant action to defeat a takeover bid. In Unocal Corp. $v$. Mesa Petroleum Co., the Delaware Supreme Court's analysis began with the explicit starting point that, in addressing a takeover bid, a board has a duty to determine whether it is in the best interests of the corporation and its shareholders, a determination "no different from any other responsibility it shoul-

Supp.). To date, the litigation committee remains a U.S. phenomenon. In Canada, a friendlier environment for shareholder litigation than the United Kingdom, courts have thus far ascribed no weight to recommendations made by litigation committees. See Brian R. Cheffins, Reforming the Derivative Action: The Canadian Experience and British Prospects, 2 COMPANY FIN. \& INSOLVENCY L. REV. 227, 253 (1997).

89. See James D. Cox \& Harry L. Munsinger, Bias in the Boardroom: Psychological Foundations and Legal Implications of Corporate Cohesion, 48 LAW \& CONTEMP. PROBS. 83, 99-108 (Summer 1985).

90. See Smith v. Croft, 3 W.L.R. 405, 442, $453-56$ (Ch. 1987). The court's willingness to permit a "majority within the minority" to defeat the plaintiff's right to pursue a derivative action may well manifest "hostility and disdain" toward the utility of derivative litigation. See A. J. Boyle, The Judicial Review of the Special Litigation Committee: The Implications for the English Derivative Action After Smith v. Croft, 11 CO. LAW. 3, 5 (1990). Unlike the U.S. precedents, the case does not authorize directors to make discretionary determinations concerning derivative suits. See ElizABETH Boros, MiNORITY SHAREHOLDERS' REMEDIES 199 (1995) (noting that Smith v. Croft requires dismissal based on determination by a majority of independent shareholders). 
ders, and its decisions should be no less entitled to the respect they otherwise would be accorded in the realm of business judgment." ${ }^{91}$ Given the risk that directors might err and act primarily in their own interest when control of the company is at issue, directors bear the burden of showing that they acted in good faith and reasonably investigated what they perceived to be a threat to "corporate policy and effectiveness." A2 Additionally, Unocal requires that the directors' action be reasonable in relation to the threat posed. Demonstrating that the defensive actions were taken in good faith is "materially enhanced... by the approval of a board comprised of a majority of outside independent directors who have acted in accordance with the foregoing standards," that is, good faith and reasonable independence. ${ }^{93}$

The court's starting point in Unocal, as well as the prominent roles it assigns to outside directors and the reviewing court, contrast sharply with the law and with takeover regulation in the United Kingdom. The leading case, Hogg $v$. Cramphorn, ${ }^{94}$ requires that shareholders ratify an allotment of new shares made by directors to defeat a threatened takeover. To the same general effect, and in great detail, the City Code on Takeovers and Mergers requires the approval of shareholders at a general meeting for actions by the board that frustrate an outstanding or an imminent bid. ${ }^{95}$ Thus, actions that Unocal characterizes as within the discretion of the board to undertake in discharging its responsibilities require, instead, submission to the shareholders for a vote. Nor is the requirement different when the board is principally comprised of outside directors. Additionally, although it has received statutory backing, the City Code is enforced by a self-regulatory body, and the leading precedents expressly discourage resort to the courts.

Central to the analysis in Unocal is the court's initial characterization: Responding to a takeover bid is no different from any other responsibility within the board's unilateral responsibility. Implicitly, the opinion acknowledges the possibility that the interests of the corporation may be different from those of its shareholders because, in evaluating the threat posed to the corporation, directors may take into account the interests of nonshareholder constituents, including employees and creditors. ${ }^{97}$ In the United Kingdom, in contrast, such a

91. 493 A.2d 946, 954 (Del. 1985).

92. Id. at 955 .

93. Id.

94. 1967 Ch. 254.

95. City Code, General Principle $7 \&$ Rule 21.

96. See The Queen v. Takeover Panel, ex parte Datafin plc, 1987 Q.B. 815 (C.A.); The Queen v. Takeover Panel, ex parte Guinness plc, 19901 Q.B. 146 (C.A.).

97. See 493 A.2d at 955 . Moreover, if the structure of the bid itself threatens shareholders' interests, remedies are likely to be available to them. In Unocal itself, the bidder proposed to buy sufficient shares for cash to give it control, and then to merge with the target in exchange for highly subordinated debt securities. Shareholders in the target who were cashed out through the merger transaction would have available a statutory appraisal remedy. See DEL. CODE ANN. tit. 8, § 262 (1998). Delaware law would also characterize the cash-out merger as self-dealing by the new controlling shareholder-the erstwhile bidder-and require the controlling shareholder to establish the "entire fairness" of the merger transaction, including the fairness of the price received by the minority. See Weinberger v. 
determination is outside of the directors' unilateral control. Unocal explicitly declines to find that all directors of a takeover target are so conflicted in their exercise of judgment that they should be required to be passive. ${ }^{98}$ As noted, though, Unocal distinguishes between outside directors-who stand to lose control of the corporation and the benefits of their office-and inside directors-who additionally stand to lose their employment and likely their principal source of income. The distinction, though, does not operate as clearly and dispositively between financially interested and disinterested directors as does the distinction drawn by safe harbor statutes discussed above. If the corporation has a majority of outside directors, Unocal treats their presence only as enhancing the directors' ability to show that they acted in good faith. Unocal does not foreclose substantive judicial review of the fit between the defensive actions and the perceived threat.

The court's ultimate resolution, moreover, departs from the consequences of its initial characterization in two respects. First, most shareholder claims that directors have abused the powers of their positions, and, in particular, that they have used corporate assets in a self-serving manner, allege injury suffered in the first instance by the corporation itself. ${ }^{99}$ Unless the shareholder alleges a separate individual injury distinct from that suffered by the corporation, the claim must be litigated through a shareholder derivative suit, a procedurally and substantively more complex vehicle than an individual action or a class, or representative, action that aggregates individual claims. Cases establishing Delaware's ground rules for responses to hostile takeovers pass over or deal summarily with the question of characterization, finding individual claims with frequency. ${ }^{100}$ What in other contexts could be significant formal questions are submerged in the court's articulation of substantive analysis to establish ground rules important to the conduct and orderly resolution of high-stakes corporate combat.

Second, unlike disputes arising from other exercises of the board's business judgment, the decisionmaking discretion of directors who respond to a takeover bid is subject to additional limits. As noted above, Unocal itself requires a reasonable relationship between the action taken by the board and the perceived threat. Later Delaware cases, beginning with Revlon, Inc. v. MacAndrews \& Forbes Holdings, Inc., ${ }^{101}$ restrict the range of the board's permissible exercise of discretion when it is inevitable that the company will be sold or

UOP, Inc., 457 A.2d 701 (Del. 1983).

98. See 493 A.2d at 955.

99. For an earlier example of a derivative suit in the context of a threatened takeover, see Cheff v. Mathes, 199 A.2d 548 (Del. 1964).

100. For a recent example, see Carmody v. Toll Bros., Inc., 723 A.2d 1180 (Del. Ch. 1998). Likewise, if the shareholder alleges conduct problematic on its face in connection with a negotiated or friendly transaction, the court is not insistent on imposing the complications of derivative litigation. See, e.g., Parnes v. Bally Entertainment Corp., 722 A.2d 1243 (Del. 1999) (allegation that corporation's CEO received improper cash payment to induce acceptance of merger proposal sufficient to establish claims of individual injury).

101. 506 A.2d 173 (Del. 1986). 
when the company itself initiates a sale. The board's duty at that point is to act in good faith to obtain the best deal available for the shareholders. Additionally, takeover responses that purposefully disenfranchise shareholders require a compelling justification. ${ }^{102}$ Even though that standard appears rarely, if ever, to be met, it does not require that a defensive mechanism with disenfranchising effects be submitted to shareholders for a vote. Instead, the court assesses the strength of the justification proffered by directors. Thus, the Delaware cases depart from the full consequences of characterizing directors' responses to takeover bids as no different from any other decision the board might make. Even with the restrictions on directors' discretion imposed by the cases, though, directors retain unilateral authority, subject to judicial review but not to shareholder vote to approve or disapprove the directors' actions. ${ }^{103}$

VI

\section{A Potemkin Village?}

It is open to debate whether investing discretion in disinterested directors is effective as a mechanism to protect the interests of shareholders. Inevitably, one next asks: "Compared with what?" 104 Professor Victor Brudney, for example, characterized the net result of the arrangements described above as a


though, Professor Brudney's preferred solutions are to prohibit selected types of transactions likely to be abusive $e^{106}$ and to empower administrative agencies to review other transactions, ${ }^{107}$ but not to mandate or enlarge the role for transaction-specific approval by shareholders. An alternative that has recently attracted attention is the shareholder-initiated adoption of bylaws that negate, mandate, or regulate specific actions otherwise within directors' managerial authority. Case law to date is sparse, apart from a recent opinion from the Oklahoma Supreme Court upholding a bylaw requiring that poison pill plans

102. See Blasius Indus., Inc. v. Atlas Corp., 564 A.2d 651 (Del. 1988). By statute, Georgia grants directors greater discretion in structuring takeover defenses that disenfranchise shareholders. See Invacare Corp. v. Healthdyne Techs., Inc., 968 F. Supp. 1578 (N.D. Ga. 1997).

103. It is not coincidental that Unocal coincided chronologically with what appears to be an enhancement of the content of directors' duty of care. In Smith v. Van Gorkom, the Delaware Supreme Court declined to defer to directors who acquiesced in the terms of a merger negotiated by their CEO because the directors lacked information relevant to the company's value, apart from the fact that the merger represented a substantial premium over the price at which the stock traded. See 488 A.2d 858 (Del. 1985). Enhancing the demands placed on directors does not suggest any general lack of confidence in the wisdom of reposing confidence in directors' capacity to exercise discretion.

104. Shareholder approval requirements may erect a Potemkin village of their own if most shareholders are apathetic and large institutional shareholders defer to directors for reasons unrelated to the interests of all shareholders. See Sheldon Leader \& Janet Dine, United Kingdom, in THE LEGAL Basis of Corporate Governance in Publicly Held Corporations: A Comparative APPROACH 219, 238 (Arthur R. Pinto \& Gustavo Visentini eds., 1998).

105. See Victor Brudney, The Independent Director-Heavenly City or Potemkin Village?, 95 HARV. L. REV. 597 (1982).

106. See Victor Brudney, Corporate Governance, Agency Costs and the Rhetoric of Contract, 85 COLUM. L. REV. 1403, 1431 n. 73 (1985).

107. See Brudney, supra note 105, at 627 n.77. 
be submitted to shareholders for a vote. ${ }^{108}$ In particular, Delaware courts have not addressed the validity of such bylaws under the Delaware statute, which enables shareholders to act unilaterally in adopting, amending, or repealing bylaws but also confers comparable unqualified power on directors. ${ }^{109}$

Empirical studies to date are not conclusive on whether independent directors make a measurable contribution to shareholder value. ${ }^{110}$ The likelihood that a board will terminate a poorly performing top executive increases with the proportion of independent directors. ${ }^{11}$ Two recent studies, one by Ira Milstein and Paul MacAvoy and one by Sanjai Bhagat and Bernard Black, reach disparate conclusions. Bhagat and Black's data find no connection between outside director dominance and shareholder value. In contrast, Millstein and MacAvoy find a significant relationship between an active independent board and corporate performance. ${ }^{112}$ Much appears to depend on the metrics chosen to evaluate the directors' performance and the time interval studied. Moreover, how great an impact corporate law has on corporate behavior and on shareholder value is itself difficult to specify, at least in isolation from product and labor markets and social norms.

A final point of contrast between the United States and the United Kingdom illustrates the complex relationships between corporate governance patterns and the style of institutional responses to recurrent problems. Takeover regulation in the United Kingdom has long included a mandatory bid requirement, applicable once a person acquires thirty percent or more of the voting

108. See International Bhd. of Teamsters Gen. Fund v. Fleming Cos., 975 P.2d 907 (Ok. 1999).

109. See Lawrence A. Hammermesh, Corporate Democracy and Stockholder-Adopted By-Laws: Taking Back the Street?, 73 TuL. L. REV. 409 (1998). In a different context, the Delaware Supreme Court held recently that any limitation on the board of directors' authority to manage the corporation's business or affairs must be contained in the certificate of incorporation. See Quickturn Design Sys., Inc. v. Shapiro, 721 A.2d 1281, 1291 (Del. 1998). In Quickturn, the court invalidated a poison pill adopted by the directors that contained a "delayed redemption" provision, which provided that no newly elected board could redeem the plan for six months after taking office in order to facilitate a transaction with a party that supported election of the new board. The Court noted the provision was additionally invalid because it might require directors to breach their fiduciary duties. See id. at 1292 . Much the same arguments could be made respecting the impact of shareholder-initiated bylaws that purport to prohibit or direct actions by directors.

110. For a citation to this extensive literature, see Michael Bradley et al., The Purposes and Accountability of the Corporation in Contemporary Society: Corporate Governance at a Crossroads, 62 LAW \& CONTEMP. PROBS. 9, 12 n.10 (Summer 1999). To function successfully, outside directors must be able to retain and exercise independent judgment in dealing with the senior executives-who may also be directors - who operate the firm on a day-to-day basis. Outside directors also must be able to obtain, at relatively low cost, information about the operational decisions that would be optimal for the firm in order to assess the performance of executive management. See Ernst Maug, Boards of Directors and Capital Structure: Alternative Forms of Corporate Restructuring, 3 J. CORP. FIN. 113, 134 (1997).

111. See James D. Cox, The ALI, Institutionalization, and Disclosure: The Quest for the Outside Director's Spine, 61 GEO. WASH. L. REV. 1233, 1241 (1993).

112. See Ira Millstein \& Paul W. MacAvoy, The Active Board of Directors and Performance of the Large Publicly Traded Corporation, 98 COLUM. L. REV. 1283, 1321 n.46 (1998).

113. See Edward B. Rock, America's Shifting Fascination with Comparative Corporate Governance, 74 WASH. U. L.Q. 367, 387 (1996). 
power in a company. ${ }^{114}$ The acquiring person must offer to buy the other shares on terms no less than the highest price that the offeror paid in the preceding twelve months. ${ }^{115}$ The mandatory bid requirement, which has no counterpart in the United States, operates to reduce the number of situations that severely test the loyalty of directors when a shareholder acquires control of a corporation. In contrast, the United States is friendlier to litigation brought by minority shareholders, ${ }^{116}$ facilitating judicial review of transactions that arguably benefit the controlling shareholder at the expense of all other shareholders, regardless of whether the directors themselves may have been disinterested. ${ }^{117}$ In an environment that is less litigation-friendly, the mandatory bid offers a different style of response to the risk that a controlling shareholder will exploit its position at the expense of the minority. ${ }^{118}$

\section{VII}

\section{CONCLUSION: A DUAL PORTRAIT?}

I began with a visual metaphor that characterized U.S. corporate law as a painting dominated by a portrait of an individual - the disinterested directorcontrasted with the U.K. landscape, which lacks a comparable figure. More accurately observed, U.S. corporate law is a dual portrait in which the court figures prominently, if somewhat less immediately in view than the disinterested director. Many contrasts, most beyond the scope of this paper, can be drawn with the United Kingdom to explain courts' prominence in the United States. The United States does not suffer from any shortage of litigation and, given an observed willingness to resort to civil litigation to resolve all manner of disputes, it is not surprising that the court is a prominent actor or figure in connection with disputes focused on corporate governance. Of great practical significance is the absence in the United States of a general rule shifting to unsuccessful litigants the costs of their successful adversaries. ${ }^{119}$

In both countries, shareholders lurk in the background of each painting, but in very different ways. Corporate law in the United Kingdom relies heavily on

114. See City Code, Rule 9.1.

115. See id. Rule 9.5.

116. The relative unfriendliness of U.K. courts is illustrated by the recent litigation, In re Astec (BSR) Plc., 2 B.C.L.C. 556 (1998), summarized in Stephen Copp \& Robert Goddard, Corporate Governance Principles on Trial, 19 COMPANY LAW. 277 (1998). Astec has a 51\% shareholder that was not subject to the mandatory bid requirement because it is resident in Hong Kong and thus not subject to the City Code. The court dismissed a shareholder claim brought under section 459 of the Companies Act 1985, alleging that Astec's controlling shareholder caused it to be run in a manner that breached the shareholder's legitimate expectations concerning corporate governance.

117. See, e.g., Kahn v. Tremont Corp., discussed supra Part IV.A.

118. La Porta, Lopez-de-Silanes, and Shleifer argue that, for most countries, corporate law reform "should focus, not on the risk of empire-building by managers, but rather on the incentives and capabilities of controlling shareholders with large equity stakes to pursue strategies that benefit them at the expense of the minority shareholders." LAPORTA ET AL., supra note 4, at 5. In countries that lack good protection for shareholders, wide dispersion in shareholding is scarce, especially among mediumsized companies. See id. at 22-23.

119. See CHEFFINS, supra note 19 , at 342. 
transaction-specific approval by shareholders to validate direct self-dealing and other types of conflict transactions, but does not require that the election of directors be structured to achieve broadly based shareholder participation. In the United States, in contrast, shareholders are significant as litigants who invoke the court's scrutiny, while shareholder voting to approve or disapprove transactions is not a mandatory legitimating device. ${ }^{120}$ Mandatory rules in the United States require that directors be elected in a manner that formally legitimates their representative relationship with shareholders. While the relative degree of dispersion in share-ownership in each country is a possible explanation for these contrasts, more than one relationship is possible between relative dispersion in share-ownership and the regulation and occurrence of self-dealing transactions.

Moreover, for some of the contrasts drawn in this article, differences in the preferred style of legal reasoning and in the perceived function of courts may be relevant. A reader of the Delaware takeover cases, trained in law in the United Kingdom, might well be surprised by the ease with which the court surmounts preliminary questions going to the plaintiff's standing and the ripeness of the dispute for adjudication, as well as whether the claim asserted in the case is properly characterized as an individual or a corporate claim that may be litigated only in a derivative action. And the reader's U.S. counterpart would be surprised by the degree to which the legacy of the rule in Foss v. Harbottle ${ }^{121}$ forecloses adjudication when directors are not alleged to have committed a nonratifiable wrong, and by the dominance of preliminary standing questions in cases like Prudential Assurance Co. v. Newman Industries, Ltd. ${ }^{122}$

120. Shareholder approval is, of course, mandated by statute for specific fundamental transactions, such as mergers and sales of all or substantially all assets. See generally Luca Enriques, The Law on Company Directors' Self-dealing: A Comparative Analysis, INT'L \& COMP. CORP. L.J. (forthcoming 2000) (surveying corporate law in the United States, United Kingdom, Italy, France, and Germany). Professor Geoffrey Miller characterizes the difference between the United States and the United Kingdom as reflecting "alternative approaches to controlling agency costs"; in the United Kingdom, the "threat or reality of a hostile takeover bid" means a firm's managers are in jeopardy of replacement if they do not maximize asset values, while in the United States, the shareholder's derivative action is more prominent. Geoffrey Miller, Political Structure and Corporate Governance: Some Points of Contrast Between the United States and England, 1998 Colum. BuS. L. REV. 52, 52 (1998). Professor Miller's explanation emphasizes differences in political structure in the two countries-the unitary system of U.K. government is more accommodating to takeovers because anti-takeover forces are significant at dispersed state-based legislation and judicial levels in the United States, and the political influence of the organized bar explains the more hospitable environment for derivative litigation in the United States. Professor Miller's account does not, however, examine how each country treats the more generic forms of self-dealing differently, or the different roles ascribed to disinterested directors and to shareholder voting.

It is also important to recognize that the structure of U.K. corporate law affects the reported aggregate number of takeover bids. The absence of statutory provisions enabling negotiated merger transactions likely means that more transactions that are entirely friendly ones commence as takeover bids in the United Kingdom than is the case for counterpart transactions in the United States. This fact is not, of course, inconsistent with Professor Miller's argument, but it does suggest that the reported level of takeover bids in the U.K. is not as threatening to incumbent management as it might initially appear to be.

121. (1843) 2 Hare 461

122. [1982] 2 W.L.R. 31 (C.A.); see also SEALY, supra note 58, at 54. 
Overall, this material may illustrate the degree to which the U.K. "vision of law tends to the formal side, while the [United States] tends to the substantive," a contrast carefully developed by Professors Patrick Atiyah and Robert Summers. ${ }^{123}$ Even the business judgment rule-which, when applicable, protects directors from liability-enables the court to make substantive threshold assessments of whether the defendant directors were disinterested and whether they acted in good faith and with adequate information, questions likely to cast some light on the presumptive merits of the transaction itself. ${ }^{124}$ Over the long haul, these kinds of differences, which go to the larger legal culture in which corporate law operates, may be more significant than differences on more specific doctrinal points because they define the range and potential of available institutions, as well as the ability of multiple institutions to complement and correct each other. ${ }^{125}$

To be sure, U.S. corporate law is in many respects as fully formal in concept and operation as its U.K. counterpart. The point of corporate law, in part, is to permit the creation of a legal person distinct from its organizers and its separate owners. Were this not the starting point, one firmly entrenched in theory as well as practice, transactions that require drawing distinctions between the corporation's property and that of its owners would be more cumbersome to effect. $^{126}$ Indeed, the intersection of agency law with contract law would make many such transactions impossible, due to the bedrock principle of agency that a principal always has power to revoke an agent's authority, despite contracting not to do so, unless the authority is granted as security for an independent pro-

123. PATRICK S. ATIYAH \& Robert S. SUMMERS, Form AND SUBSTANCE IN ANGLO-AMERICAN LAW: A COMPARATIVE STUdy OF LEGAl REASONING, LEGAL THEORY, AND LEGAL INSTITUTIONS 415 (1987).

124. If these questions arise in a derivative suit in a Delaware corporation, the context is likely to be whether the plaintiff must make a demand on the corporation's directors prior to filing suit, or whether the plaintiff's failure to make a demand is excusable because making the demand would have been futile. Despite its complexities, the gist of the Delaware doctrine is whether a majority of the corporation's directors, as to the transaction challenged by the derivative suit, made a decision that would be protected by the business judgment doctrine.

125. Relatedly, Professor Gower noted that

English courts tend to be strict when they have a rule of thumb to apply, such as the rule that directors must not take personal advantage of a corporate opportunity. They move with less assurance when they have no fixed standard to guide them. American courts are perhaps rather more ready, or perhaps one should say less unready, to hold that directors' action exceeds the permissible bounds of their business judgment.

Gower, supra note 3, at 1383.

126. Moreover, it is not possible to justify the corporate veil principle that insulates shareholders from corporate obligations unless the corporation's formally separate existence is taken seriously. But see FrANK H. EASTERBROOK \& DANIEL B. Fischel, THE ECONOMIC STRUCTURE OF CORPORATE LAW 41 (1991) (stating that "[i]f limited liability were not the starting point in corporate law, firms would create it by contract"). A nonparty would, of course, not be bound by an attempt to create limited liability through agreement. Some contractualist accounts of corporate law, in an attempt to maintain contact with descriptive accuracy, define contract very expansively, to encompass nonexcludable mandatory rules of law and other elements in the parties' association that do not result from any real bargaining. See Ross Grantham, The Doctrinal Basis of the Rights of Company Shareholders, 57 CAMBRIDGE L.J. 554, 580 (1998). 
prietary interest of the agent's. ${ }^{127}$ In a contractually constituted association, that is, one in which directors were no more than shareholders' agents, their power to bind shareholders to third parties-often to the advantage of all shareholders-would be unstable. That corporate law reflects a necessary formalism does not, of course, specify the degree or extent to which interests should be ascribed to the corporation that are distinct from its owners' interests. $^{128}$ Nor does the corporation's distinct identity, separate from its shareholders, entail that directors may exercise discretion to further interests at odds with those of shareholders. ${ }^{129}$

Only the most self-confident of aesthetes would categorically endorse a preference for portraits over landscapes. Many factors, I have suggested, help explain the contrasts between the landscape presented by U.K. corporate law and its counterpart portrait in the United States. The criterion by which each should be assessed is its contribution to adaptive efficiency, that is to the "trials, experiments, and innovations" requisite to creative activity and the resolution of problems over time. ${ }^{130}$ Comparisons between legal systems may be helpful in this regard because they illustrate the possibility of alternate doctrines and institutions as well as their limitations. Comparisons of systems that are similar in many respects, but divergent in others, also suggest that convergence over time is not an all-or-nothing phenomenon. In particular, similar capital market

127. See Francis Reynolds, When Is an Agent's Authority Irrevocable?, in MAKING COMMERCIAL LAW 259 (Ross Cranston ed., 1997). Moreover, the doctrines examined in this article illustrate the d egree to which corporate law in the United Kingdom and the United States has in significant respects pulled away from the general law into its distinct and separate realm. In general law, for example, a fiduciary's contract with a beneficiary as to matters within the scope of their relationship is voidable by the beneficiary unless it is on fair terms and unless all beneficiaries manifest assent with full understanding of their legal rights and all relevant facts that the fiduciary knows or should know. See RESTATEMENT (SECOND) OF CONTRACTS $§ 173$ (1981). This principle is at odds with the role assigned to disinterested directors in U.S. corporate law, as well as with the majoritarian norm applicable to shareholder voting in U.K. corporate law.

128. As with any formal construct, dispute is always possible over how far one should take its consequences. It is not helpful simply to characterize the construct as a fiction. Consider in this light J.L. Austin's insights into a related practice-pretending. When we pretend, as when we deem a corporation to be a legally separate person, we are treating one thing as something else. Professor Austin wrote:

[T]here are in fact, as we should expect, ways in which limits and the overstepping of limits are relevant to the concept of pretending, as to so many others. On a festive occasion you are ordered, for a forfeit, to pretend to be a hyena: going down on all fours, you make a few attempts at hideous laughter and finally bite my calf, taking, with a touch of realism possibly exceeding your hopes, a fair-sized piece right out of it. Beyond question you have gone too far.

J.L. Austin, Pretending, in PhilosophiCAl PAPERs 201, 204 (J.O. Urmson \& G.J. Warnock eds., 1970) (footnote omitted). The footnote to this passage states: "In these circumstances. But if Nero ordered you, in the arena, to pretend to be a hyena, it might be unwisely perfunctory not to take a piece right out." Id. n.1 (emphasis in original).

129. It is thus not necessary to argue that the corporation is not a "distinct and identifiable entity" as a step in an argument that directors' decisions should be made to further the interests of shareholders. See Bradley et al., supra note 110 , at 35.

130. Douglass C. North, Institutions, Institutional Change and Economic Performance 80-81 (1990). See also Ronald J. Gilson, Corporate Governance and Economic Efficiency: When Do Institutions Matter?, 74 WASH. U. L.Q. 327, 342-45 (1996). 
mechanisms may co-exist with divergent internal approaches to governance. Changes in corporate governance patterns are not likely to erase distinctive local traits, given the dependence of corporate governance on broader social practices and the larger legal culture. 